4. Gibbons RD, Brown $\mathrm{CH}$, Hur K et al. Suicidal thoughts and behavior with antidepressant treatment. Reanalysis of the randomized placebo-controlled studies of fluoxethine and venlafaxine. Arch Gen Psychiatry 2012; 69: $580-7$.

5. Spielmans GI, Jureidini J, Healy D et al. Inappropriate data and measures lead to questionable conclusions. JAMA Psychiatry 2013; 70: 121-2.

6. Carroll BJ. Suicide risk and efficacy of antidepressant drugs. JAMA Psychiatry 2013; 70: $123-4$

7. Gibbons RD, Brown $\mathrm{CH}$, Hur $\mathrm{K}$ et al. Suicide risk and efficacy of antidepressant drugs - reply. JAMA Psychiatry 2013; 70: 122-5.

Dette er en redigert versjon av et innlegg publisert som rask respons på nett 12.3. 2013. http://tidsskriftet.no/article/2975531/

\section{A.E. Vaaler \& O.B. Fasmer svarer:}

Det er gjort en rekke metaanalyser vedrørende forskjeller mellom antidepressive legemidler og placebo. Det er mulig å kritisere metodevalget $i$ alle slike arbeider. Vi viser til to arbeider som anses å være sentrale. Det finnes metaanalyser med mer positive eller mer negative resultater i forhold til placebo enn våre to nevnte. Og det finnes metaanalyser som ikke viser noen fordel for antidepressiver sammenliknet med placebo overhodet (1).

Kronikkformen har plassbegrensninger som gjør at ikke alle aspekter av temaet antidepressive legemidler kan tas med. Effekter av ulike terapiformer ved depresjoner og medikamentelle alternativer til antidepressive legemidler er eksempler på dette. I vår kronikk omtalte vi heller ikke de hyppig forekommende somatiske bivirkninger av antidepressive legemidler, for eksempel seksuelle dysfunksjoner. Det samme gjelder restsymptomer og redusert livskvalitet hos deprimerte pasienter som er vurdert å ha klinisk effekt av antidepressive legemidler. Nye data tyder på at dette er et betydelig klinisk problem - opptil $60 \%$ av pasientene er beskrevet med en slik tilstand (2).

I studier av langtidsbruk av antidepressive legemidler er det rapportert færre tilbakefall hos pasienter som fortsetter med uendret medisinering sammenliknet med dem som bytter ut aktivt medikament med placebo. Denne forskjellen er imidlertid begrenset til de første seks måneder. Deretter er det ingen forskjell. Data tyder på at de rapporterte positive resultater til fordel for langtidsbruk av antidepressiver for en stor del skyldes primær toleranseutvikling og abstinens etter seponering i gruppen av pasienter som bytter til placebo (3). Lengre eksponering for antidepressive legemidler forut for randomisering til placebo gir økt risiko for tilbakefall (4).

Vår kronikk konkluderte med at vi trenger legemiddelinformasjon fra uavhengige kilder. Slik informasjon vil endre forskrivningspraksisen. Vi påpekte at legemiddelindustrien driver ukritisk markedsføring - bivirkninger bagatelliseres og kritiske argumenter blir ikke tatt seriøst. Legemiddelindustriens svar på kronikken mer bekrefter enn avkrefter vår konklusjon.

\section{Arne E. Vaaler}

arne.e.vaaler@ntnu.no

Ole Bernt Fasmer

Arne E. Vaaler (f. 1954) er førsteamanuensis ved Norges teknisk-naturvitenskapelige universitet og overlege ved Seksjon for akuttpsykiatri, St. Olavs hospital.

Ingen oppgitte interessekonflikter.

Ole Bernt Fasmer (f. 1952) er professor dr.med. og leder ved Seksjon for psykiatri, Institutt for klinisk medisin, Universitetet i Bergen, og undervisningsansvarlig i Psykiatrisk divisjon, Helse Bergen.

Ingen oppgitte interessekonflikter.

\section{Litteratur}

1. Barbui C, Furukawa TA, Capriani A. Effectiveness of paroxetine in the treatment of acute major depression in adults: a systematic re-examination of published and unpublished data from randomized trials. CMAJ 2008; 178: 296-305.

2. Price J, Cole V, Goodwin GM. Emotional side-effects of selective serotonin reuptake inhibitors: qualitative study. Br J Psychiatry 2009; 195: $211-7$.

3. El-Mallakh RS, Briscoe B. Studies of long-term use of antidepressants: how should the data from them be interpreted? CNS Drugs 2012; 26: 97-109.

4. Viguera AC, Baldessarini RJ, Friedberg J. Discontinuing antidepressant treatment in major depression. Harv Rev Psychiatry 1998; 5: 293-306.

\section{Den Gud gir et embete}

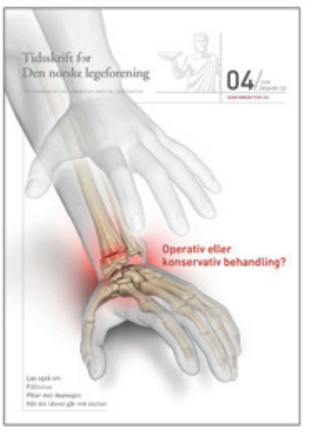

En artikkel i Tidsskriftet nr. 4/2012 omhandlet bl.a. ordspråket «Den Gud gir et embete, gir han også forstand» (1). Om det bare var så enkelt, ville jo det meste bli bra. Det kan imidlertid diskuteres om ordspråket egentlig er slik.

Elisabeth Swensen har hevdet at den opprinnelige ordlyden antakelig er «Den Gud giver et embede»... den give Han også forstand» - det vil si at ordspråket inneholder et imperativ snarere enn en påstand. Swensen mener forskjellen i betydning er «potensielt katastrofal» (2).

Mot den ordinære forståelsen om at det automatisk følger klokskap med makt, setter Swensen bønnen om at den som får en betrodd stilling, også må få forstand. Jeg er enig med henne i at forskjellen er potensielt katastrofal dersom den som får embetet, tror at forstanden automatisk følger med, og/eller hvis den som utnevner, tror det samme.

\section{Kåre Ertresvåg}

karearne@gmail.com

Kåre Ertresvåg (f. 1940) er spesialist i generell kirurgi og overlege ved Diakonhjemmet Sykehus

Ingen oppgitte interessekonflikter.

\section{Litteratur}

1. Lærum OD. Styring av vitenskap på ville veier. Tidsskr Nor Legeforen 2013; 133: 441-4.

2. Swensen E. Den Gud giver et embete... Hovedforelesning på primærmedisinsk uke 2012. http://elswense.wordpress.com/2012/12/08/den-gud-giver-etembede-hovedforelesning-pa-primaermedisinsk-uke-2012/ (19.2.2013).

Dette er en redigert versjon av et innlegg publisert som rask respons på nett 19.2. 2013. http://tidsskriftet.no/article/2976306/ 